\title{
The Influence of Bait on the Fishing of Sakuda(Lethrinidae Family) Using Fishing Line
}

\author{
Julius Mose Rahaningmas ${ }^{1}$, Meiksyana Raynold Renjaan ${ }^{2}$ \\ ${ }^{I}$ Department of Technology of Fishery Products Prodi Management of Capture Fishery Engineering, Poltek \\ Tual, 97611, Maluku, Indonesia. \\ ${ }^{2}$ Department of Fishery Product Technology Prodi Fishery Agribusiness, PoltekTual, 97611, Maluku, Indonesia
}

*Corresponding Author: Julius Mose Rahaningmas, Department of Technology of Fishery Products Prodi Management of Capture Fishery Engineering, Poltek Tual, 97611, Maluku, Indonesia.

\begin{abstract}
In the Kei archipelago, Southeast Maluku there are many Sakuda fish (lethrinidae family) so it requires accurate analysis to increase productivity. The effectiveness and productivity of sakuda fish catch (lethrinidae family) is strongly influenced by bait and time. The types of bait used are crab, rice, anchovy and wheat flour. The objectives of the study were 1) to determine the types of baits that were faster to catch the fish sakuda and 2) to determine the most effective time to catch of sakuda fish large quantities. The research method used is comparative descriptive analysis to see the difference of fishing time. While statistical analysis of ANOVA Completely Randomized Design (RAL) was used to see the effect of bait type on catch amount. This research was conducted for 24 days in Watdek waters, Kei Islands, Southeast Maluku. The results showed that more crab bait catch sakuda fish (family lethrinidae) that is 212 tail or 54\%. The best time for sakuda fishing operation (lethrinidae family) is at 14.00-16.00 pm as much as 206 tail or 52\%.
\end{abstract}

Keywords: Crab, Rice, Anchovy, Wheat Flour, Fishing line

\section{INTRODUCTION}

Southeast Maluku includes an archipelago area that is almost largely rocky bottom waters. One of them is Watdek waters, Kei Kecil subdistrict, Southeast Maluku district. Hoshino et al. (2016) explains that rocky waters such as the waters of the Keiselal archipelago are made by reef fish and demersal as a place of life. One is the type of sakuda fish (family lethrinidae).The sakuda fish resources (lethrinidae family) are scattered in almost all Indonesian waters, including the waters of Maluku (Matruttyet al., 2013). Fishermen use fishing lines to catch them. The types of fishing gear that fishermen use to catch sakuda fish are bubu, gill nets and fishing line.Of the three types of fishing gear, fishermen more use fishing rods to catch sakuda fish.Rahaningmas et al. (2014) explains that fishermen love fishing line because it has several advantages that is easy to construct construction, easy to make construction fishing line and can be operated in various depth waters and the quality of fish catch is always good.The success of the sakuda fishing operation with the fishing line is highly determined by the bait. Siswoko et al. (2013) explains that a good bait is a bait whose function is to invite or stimulate fish so that fishing operations will be more effective. The type of bait that is always used by fishermen are crab, rice, anchovy and wheat flour.Types of sakuda fish (lethrinidae family) caught during the study were the fish sakuda karang (lethrinus erythropterus), the fish sakuda pasir (Letrinus obsoletus) and the fish sakuda pelong (letrinus harak).The three types of sakuda (family lethrinidae) have differences in length and color. The length of fish sakuda coral ranges from 30-50 $\mathrm{cm}$.Head and body are brown or red rust. Wide white lines are in the eye to the tip of the snout. The lips and base of the pectoral fin are red. The fins are reddish, often red or orange.The length of the sand pocket is $20-60 \mathrm{~cm}$. The mouth is slightly prominent, his lips are thick and fleshy. The back scales are sometimes white. Large elliptical spots, often flanked in yellow, on the right side below the lateral line and centered on the vertical near the posterior end of the pectoral fin. Sometimes the light blue dots are round the eyes and around the nostrils. The dorsal and rectal fins are white or pink. The orange tail fins or redness and vertical fins are sometimes mottled.fish sakuda pelong have a length of between $20-50 \mathrm{~cm}$. Body is light brown or olive to brown. His head often has several dark vertical and diagonal bands. Sometimes there are white spots under the eyes. The posterior part of the opercum is 
dark brown and the orange yellow line is on the bottom. There are also two slightly fainteryellowstripes above and one below. The fins are whitish or brownish, sometimes mottled. The morphology of the sakuda (lethrinidae family) caught during the study is shown in Figure 3.

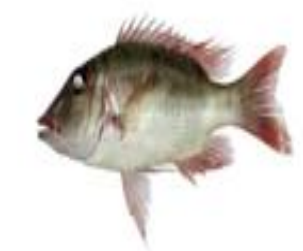

Sakuda Karang
(Lethrimus erythropterus)

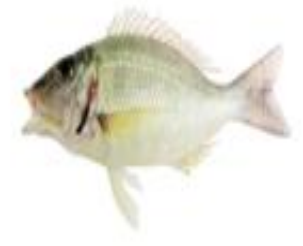

Sakuda Pasir
(Lethrinus obsoletus)

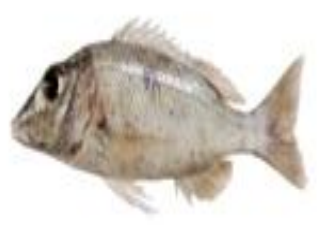

Sakuda Pelong

(Letrinus harak)

Figure3:Types of Sakuda Fish (LethrinidaeFamily)

Use of an effective bait for catching a pocket fish does not yet exist. This is evidenced by the provision of four types of bait that is crab, rice, anchovy and wheat flour are always prepared by the fishermen before leaving to go to sea.One effort must be made to ensure the type of bait most favored by the sakuda is to conduct research.The objectives of the study were 1) to determine the types of baits that were faster to catch the fish sakuda and 2) to determine the most effective time to catch of sakuda fish large quantities.

\section{RESEARCH METHODS}

The research activities were carried out in two stages, ie 1) determination of research location, determination of bait type and timing of fishing and 2) fishing trials. The activity took place in March - May 2017. Research location in waters Watdek, Southeast Maluku. Figure 1 shows the location of the study.

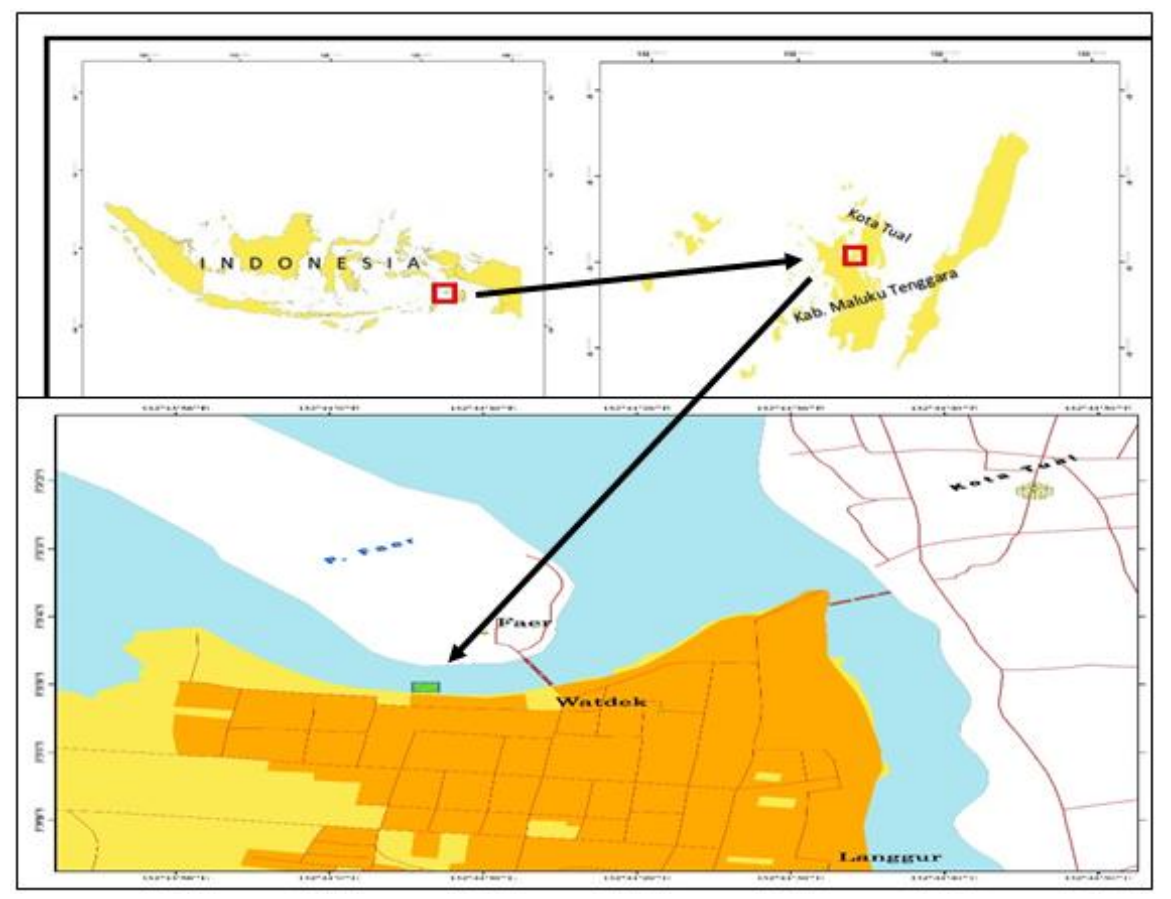

Fig1:Location of the Study

\subsection{Tools and Materials}

The equipment used consists of the main equipment including one speed boat unit, $\varnothing 18 \mathrm{~cm}$ plastic roller, polyamide rope (PA) monofilament number 600, kili-kili, hook number 9, tin weights @ 1.5 $\mathrm{kg}$. The supporting equipment consists of a charter knife and a ruler with a precision of $1 \mathrm{~mm}$. The types of materials used during the research are crab, rice, anchovy and wheat flour. 
The fishing line construction and the four types of bait can be seen in Figure 2 .

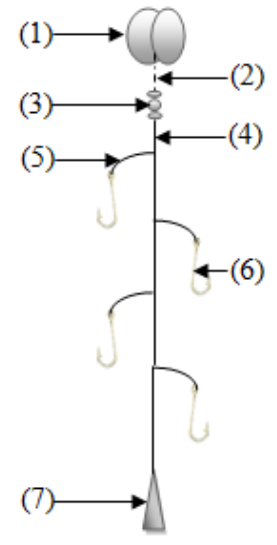

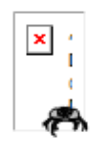

(8)

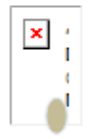

(9)

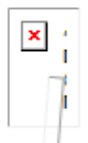

(10)

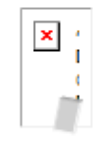

(11)

Keterangan :

1) Plastic roller;

2) Fishing line;

3) Kili-kili;

4) The main rope;

5) Branch rope;

6) Fishhook;

7) Weighing tin @ $1.5 \mathrm{~kg}$;

8) Crab bait;

9) Rice bait;

10) Anchovy bait; and

11) Wheat flour bait

Figure2: Construction of Handlinesand Type Of Bait

\subsection{Research methods}

This research uses experimental method by conducting field test directly.Sakuda fishing operations are conducted between 06:00 and 18:00 pm divided into four time groups, ie 6:00 am to 8:00 pm, 8:00 pm-10:00 pm, 14:00 pm to $16: 00 \mathrm{pm}$ and 16:00 to 18:00 pm.Distance from coast to catching area \pm 1 mile with water depth about $50 \mathrm{~m}$. Four individually operated fishing rods are composed of 4 eye fishing rods. Each fishing line uses crab bait, rice, anchovy and flour. The type of bait that fishermen use is exchanged on each fishing ground. Figure 3 shows the Order of Sakuda Fishing Operation (LethrinidaeFamily).

Stages of fishing fish Sakuda (Lethrinidae Family)

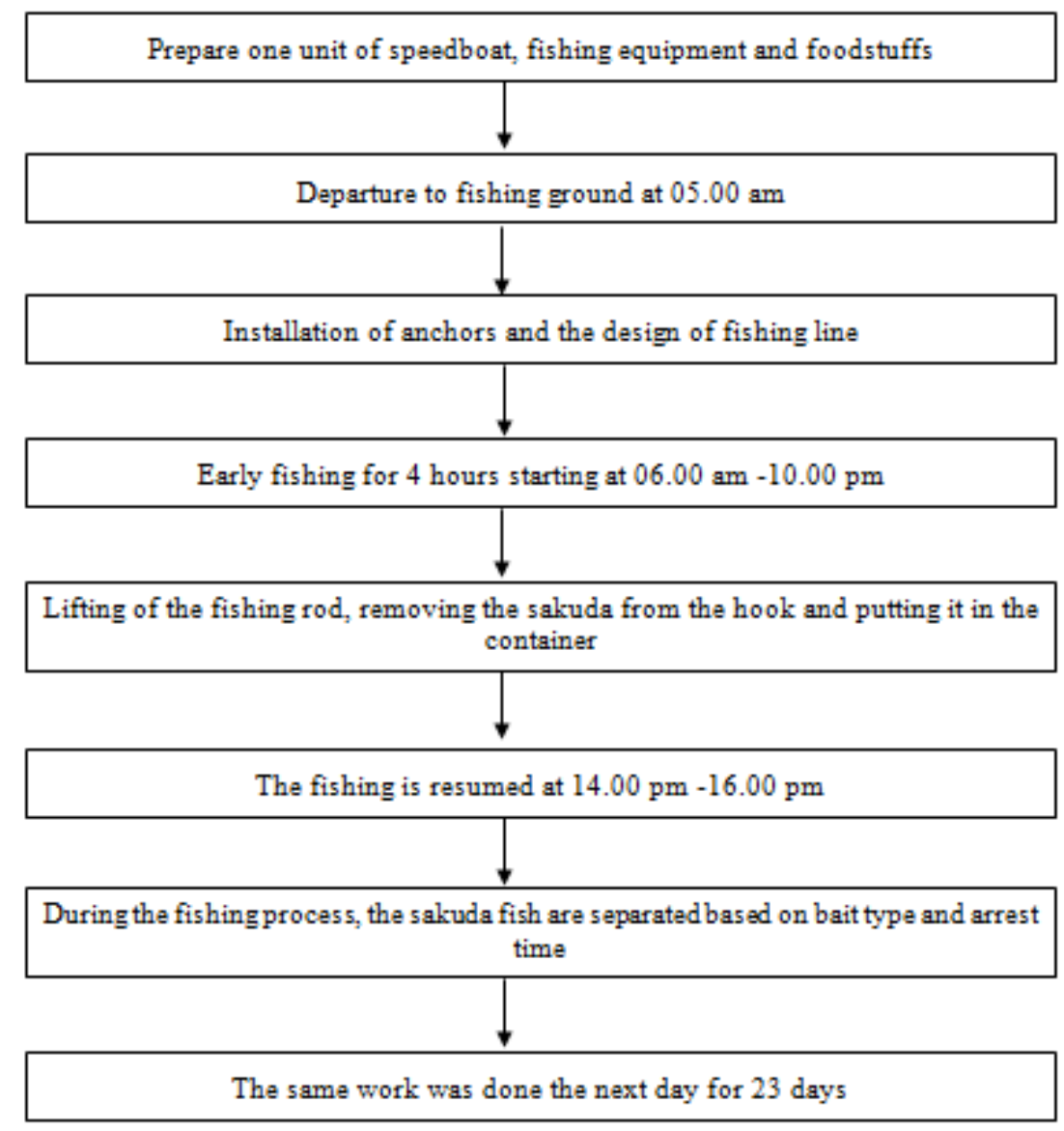

Figure3:Sequence of Sakuda Fishing Operations (Lethrinidae Family) 


\subsection{Data analysis}

This study uses two kinds of data analysis, namely descriptive analysis used to see the difference in the time of catching the catch. The complete randomized ANOVA statistical analysis (RAL) was used to see the effect of bait type on the number of catches.

Yijk $=\mu+\tau i+\delta i j+\varepsilon i j k ; i=1,2,3, \ldots$ etc $;$ And $j=1,2,3 \ldots$ etc

Yijk is the observation of the i-th-treatment, the repetition of $j$-th and subsample of the k-th sample child; $\mu$ average middle population; $\tau i$ : $i$-th treatment; $\delta$ ij: the effect of the $j$-threpetition, the treatment of i-th; andeijk: error subsample. The assumptions required for this analysis are 1) additive, homogeneous, free, and normal; 2) $\tau \mathrm{i}$ is permanent; and 3) cijk $\sim \mathrm{N}(0, \delta 2)$.

The hypotheses tested are:

Ho: $\tau 1=\tau 2=\tau 3=\ldots \ldots .=\mathrm{T} 5=0$; and

Ho: $\tau 1=\tau 2=\tau 3=\ldots \ldots .=\mathrm{T} 5 \neq 0$

The conclusion obtained is if Fhit $>$ Ftab, then $\mathrm{H}_{0}$ is rejected and $\mathrm{H}_{1}$ accepted, then if Fhit $<$ Ftab, then $\mathrm{H}_{0}$ is accepted and $\mathrm{H}_{1}$ is rejected.

\section{RESUlT}

Thecatch of fish sakuda for 24 days amounted to 393 tail and the number of catches varies. this can be seen in figure 4

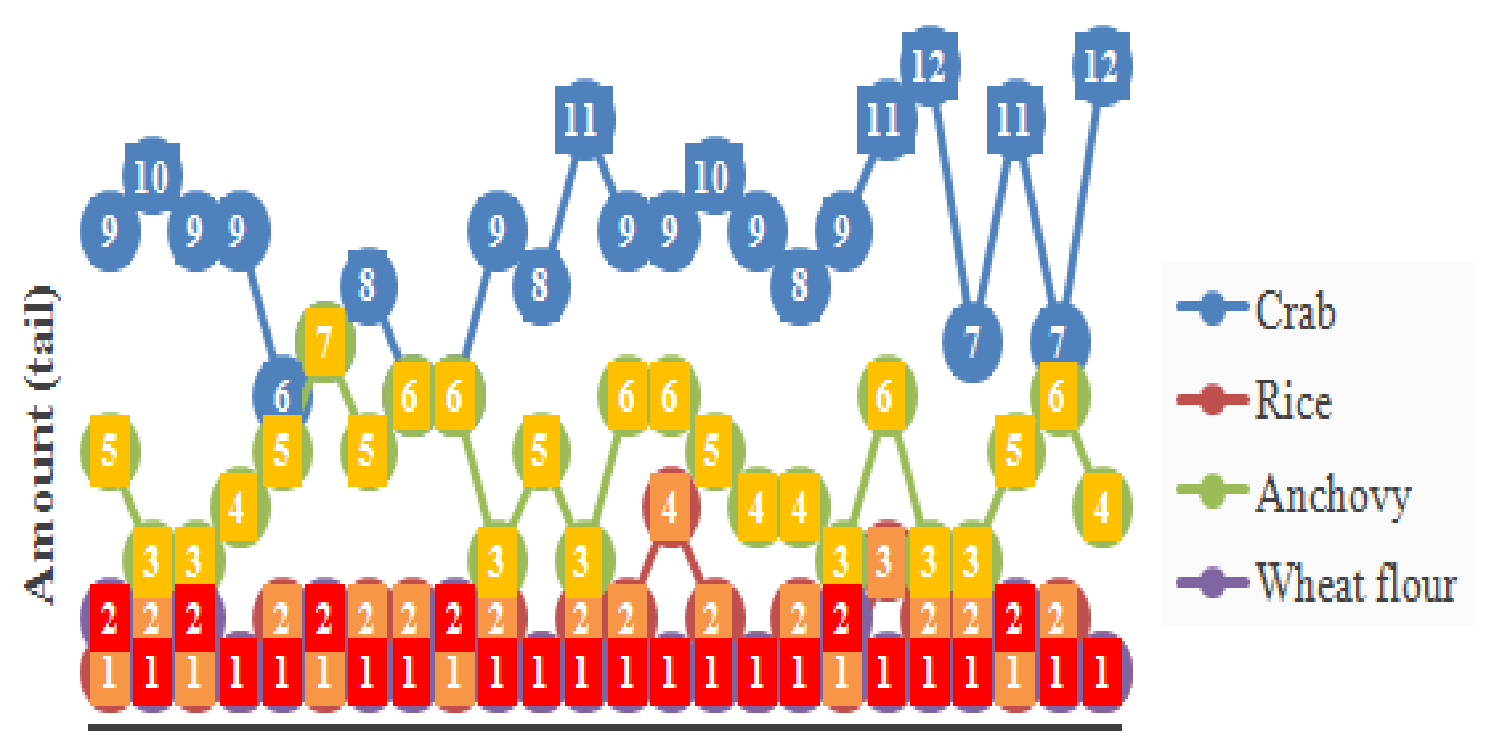

123456789101112131415161718192021222324

\section{Amount (day)}

Figure4:Number of Sakuda Fish Catch (Lethrinidae Family) per day based on the type of bait

The types of bait used during the study were crab, rice, anchovy and flour. Among the four types of these baits, crabs catch sakuda fish in large numbers that is between 6 to 12 tails per day.Anchovybaits acquire sakuda fish as much as 2-7 fish per day.Thenumber of sakuda fish caught with rice bait as much as 1-4 tails per day and wheat flour get a catch of fish sakuda amounted to 1-2 tails per day.

\subsection{ResultCatching Based on Bait Types}

The results of the sakuda fishing operation (lethrinidae family) showed that the four types of baits of both crab, rice, anchovy and wheat flour highly responded by sakuda fish.The number of sakuda fish catches based on type of bait is presented in Figure 5. 


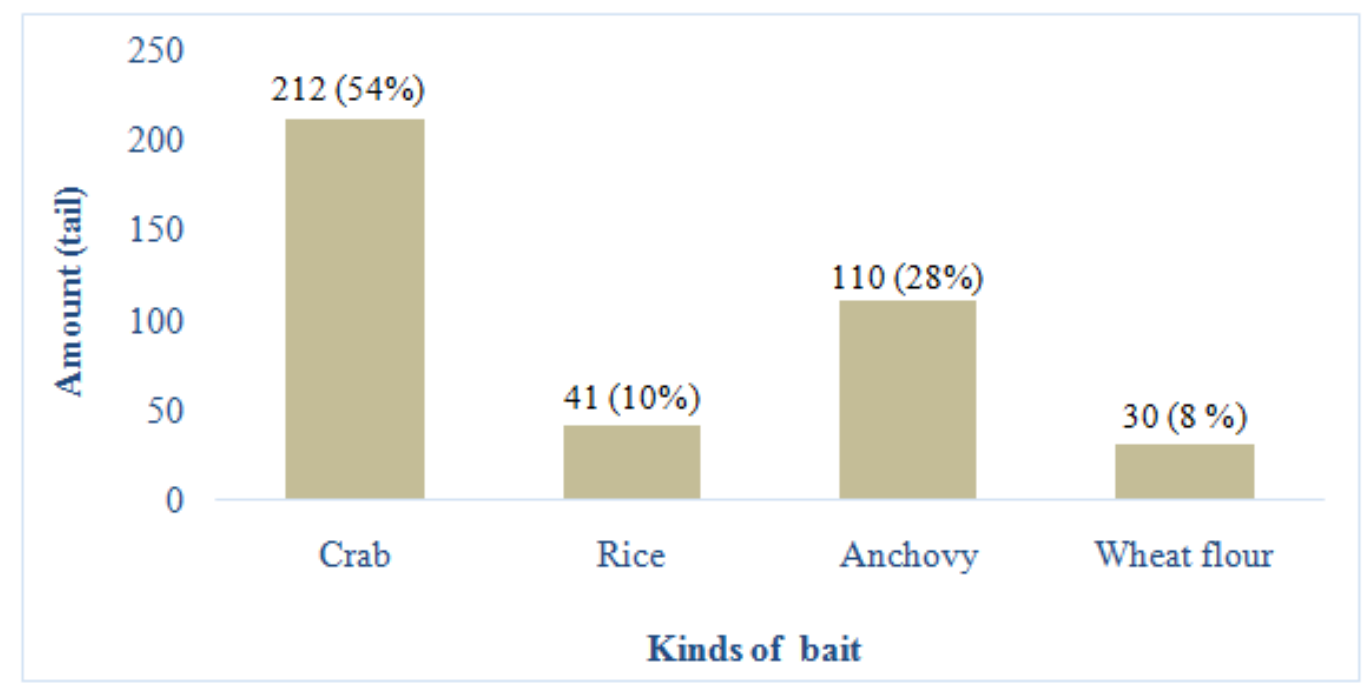

Figure5:Number of Sakuda Fish Catch (lethrinidae family) based onBait type

The number of sakuda fish catches with crab bait more than the other three types of bait, that is 212 or $54 \%$. Anchovy is capture 110 tail or $28 \%$. Rice bait 41 tail (10\%) and wheat flour is capture 30 tail $(8 \%)$.

\subsection{The Catch Based on Time of Fishing}

Fishing time during the study was divided into four periods, namely; at $06.00-08.00 \mathrm{pm}$, at 08.00 $10.00 \mathrm{pm}$, at $14.00-16.00 \mathrm{pm}$ and at $16.00-18.00 \mathrm{pm}$. The number of catch fish sakuda based on the four fishing periods can be shown in Figure 6.

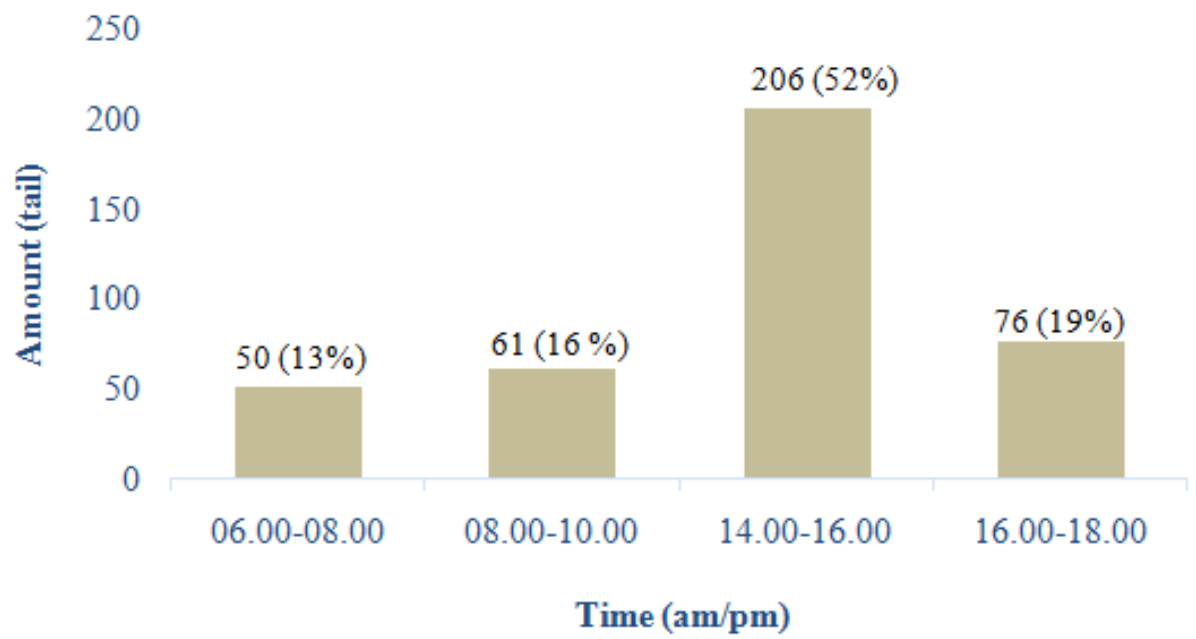

Figure6:Number of sakuda fish catch (family lethrinidae)

based on fishing time

The period of operation of sakuda fishing (lethrinidae family) at intervals between 14.00-16.00 pm gives the largest number of catches, that is 206 tail or $52 \%$. Furthermore, at 16:00 to $18: 00 \mathrm{pm}$ is second in the number of catches of 76 tail (19\%). Period between $08.00-10.00 \mathrm{pm}$ ranks third, which is 61 tail $(16 \%)$. And fishing time at $06.00-08.00 \mathrm{pm}$ get the lowest amount of fish catch, 50 tail or $13 \%$.

\section{DISCUSSION}

The number of sakuda fish catches during the study was 393 tails. This result is obtained from 24 times of fishing using four types of bait.Consisting of sakuda fish caught using crab bait as much as 6 to 12 tails per day.Bait teri get 2-7 tails per day. Furthermore, rice baits catch fish sakuda as much 1-4 tail per day. And wheat flour bait catch sakuda fish only ranged between 1-2 tail per day.Based on the data of catch fish sakuda per day above, shows that the resource fish sakuda are still available in Watdek waters, Southeast Maluku. 


\subsection{ResultCatching Based on Bait Types}

The fish sakuda (lethrinidae family) responds greatly to crab, rice, anchovy and wheat flour bait as these four baits can invite or stimulate sakuda fish to approach them.

ANOVA statistical test result of complete randomized design at $95 \%$ confidence level $(\alpha=0,05)$ is Fhit $=205,55>$ Ftab $=2,70$. This means H0 is rejected and H1 is accepted. So the conclusion is that the number of sakuda fish (lethrinidae family) caught by four different baits is real.The type of crab bait catches more sakuda fish is 212 tail or $54 \%$. This happens because allegedly the sakuda fish (lethrinidae family) is very familiar body shape, color and bauhnya because dwelling crab very close to the fish sakuda so that the fish sakuda come near the crab to eat it.Furthermore, the number of sakuda catches using anchovy baits ranked second largest after crab bait is 110 tails or $28 \%$.

This is due to the suspected fish anchovy less durable when compared with the smell of crabs so that the fish sakuda faster approaching the crab bait. According to Imam et al. (2016) explains that the main food of fish sakuda (family lethrinidae) is crustacea (crab and shrimp), molusca (gastropod, bivalvia, nudri branch, squid and small octopus), echinodermata (sea urchins, stars star, starfish, brittlestar ), polychaeta, and small fish (tembang and teri).

The catch of sakuda fish with rice and wheat flour is in third and fourth order, each of which is 41 tail (10\%) and 30 tail (8\%). Sakuda fish that caught with rice and wheat flour baits allegedly fish sakuda that lose competing to prey on crab bait and anchovy.

Noija et al. (2014) explains that fish sakuda (lethrinidae family) belongs to a greedy carnivorous species and belongs to a predatory type that preys on food also favored by other marine biota.

\subsection{The Catch Based on Time of Fishing}

Sakuda fishing operation at intervals between 14.00-16.00 pm gives the largest number of catches, which is 206 tail or 52\%. This happens because the low tide currents begin to stop and the state of very quiet waters so that the activity of eating not disturbed. According to Mujiyanto (2014) added that the fish sakuda (family lethrinidae) including demersal fish that looking for food in groups.

Sakuda fishing activity at $16.00-18.00 \mathrm{pm}$ is in second place in the acquisition of the number of catches that is 76 tails (19\%). This happens because the condition of the waters in this period began to not calm, the current began to move so it is very disturbing eating activities. The results of the study Muchtar et al. (2014) explains that in general the lethrinidae family sought to feed in the reef area around rubble and began to seek shelter in the late afternoon to rest.

Fishing time at 06.00-08.00 get the lowest number of catches (lethrinidae family), 50 tail or $13 \%$.Activity activities have not reached the peak so that the number of sakuda fish that caught very little.In addition, the caught fish were suspected to have just come out of their hiding place and passed through the fishing grounds.According to Iskandar (2011), the sakuda (lethrinidae family) that was caught was suspected to be just out of the coral horizontally for feeding so that it directly preyed on the bait around the rubble and the coral reef area.

\section{CONCLUSION}

The results showed that crab bait can catch sakuda fish (lethrinidae family) in large quantities.This is evidenced by the number of sakuda fish catches using crab bait get 212 tail or $54 \%$. anchovy as much as 110 tail or $28 \%$, rice bait amounted to 41 tail or $10 \%$, and wheat flour bait only catch 30 tail or $8 \%$.

The best time to catch fish sakuda (lethrinidae family) is 14: 00-16: $00 \mathrm{pm}$ which produces 206 tail or 52\%, 16: 00-18: $00 \mathrm{pm}$ as much 76 tail (19\%), 08: 00- 10:00 pm earn 61 tail (16\%) and at 06: 00-08: $00 \mathrm{pm}$ is 50 tail or $13 \%$.

\section{SUGGESTIONS}

Thesame study must be conducted on sandy and muddy waters

\section{ACKNOWLEDGMENTS}

We would like to thank the Ministry of Research and Technology with the decentralization policy of research by Directorate General of Reinforcement Risbang who has provided research grant through SIMLIBTAMAS RISTEKDIKTI in Beginner Lecturer Research Program (PDP) 


\section{REFERENCES}

[1] de Vasconcellos AV, Lima D, Bonhomme F, Vianna M, Solé-Cava AM, 2015. Genetic population structure of the commercially most important demersal fish in the Southwest Atlantic: The whitemouth croaker (Micropogonias furnieri). Journal Fisheries Research 167:333-337.

[2] Hoshino EI, Van Putten I, Girsang W, Resosudarmo BP, Yamazaki S, 2016. A Bayesian belief network model for community-based coastal resource management in the Kei Islans, Indonesia. Ecology and Society 21(2):16.

[3] Imam SA, Alsabaani A, 2016. On Peripheral Hemogram Of Edible Fish Lethrinus Nebulosus (Lethrinidae Family) Available In Fish Market In Abha City, Assir Region, Saudi Arabia. Imperial Journal of Interdisciplinary Research 2(12):1943-1946.

[4] Iskandar D, 2011. Bycatch Analyses of Pot Operated In Cora 1 Reef Waters of Seribu Islands. Jurnal Saintek Perikanan 6(2):31-37

[5] IUCN 2016. Ikan Sakuda karang (Lethrinus erythropterus) [internet]. [diunduh 2017 Juni 21]. Tersedia pada http://www.iucnredlist.org/details/16720002/0

[6] IUCN 2016. Ikan Sakuda pasir (Lethrinus obsoletus) [internet]. [diunduh 2017 Juni 21]. Tersedia pada http://www.iucnredlist.org/details/16720267/0

[7] IUCN 2016. Ikan Sakuda pelong (Letrinus harak) [internet]. [diunduh 2017 Juni 21]. Tersedia pada http://www.iucnredlist.org/details/16720022/0

[8] Matrutty DDP, Waileruny W, Nioja D, 2017. Value system of pasi as a type of community based management of fisheries resources in Lease Islands, Maluku, Indonesia. Aquaculture, Aquarium, Conservation \& Legislation - International Journal of the Bioflux Society 10(1):25-31.

[9] Muchtar AS, Sadarun B, Siang RD, 2014. Benefit Analysis Of Coral Fishing Effort in Wawatu Village Northern Moramo Subdistric of Southern Konawe Regency. Journal of fishery business 1(1):63-74.

[10] Mujiyanto, 2014. Community Fish in Coral reef in the Semak Daun Island, Seribu Island. Jurnal Akuatika 5(2): 112-124.

[11] Noija D, Martasuganda S, Murdiyanto B, Taurusman AA, 2014. Potential And Utilization Of Water Resources In The Island Demersal Ambon Province Maluku. Jurnal Teknologi Perikanan dan Kelautan 5(1): 55-64.

[12] Rahaningmas JM, Puspito G, Diniah, Wahju RI, 2014. Hairtails Fishing (Trichiurus sp.) Effectiveness Using Artificial Bait. Jurnal Teknologi Perikanan dan Kelautan, 5(1): 33-40.

[13] Siswoko P, Pramonowibowo, Fitri ADP, 2013. The Effect of a Difference Bait Type and Hook Type toward the Fish Catching Use Fishing Rod Coping (hand line) in The Fishing Ground Waters of Pacitan, East Java. Journal of Fisheries Resources Utilization Management and Technology, 2(1): 66-75.

Citation: J. M. Rahaningmas, M. R. Renjaan, "The Influence of Bait on the Fishing of Sakuda (Lethrinidae Family) Using Fishing Line“, International Journal of Innovative Studies in Aquatic Biology and Fisheries, vol. 4, no.1, p. 13-19, 2018. http://dx.doi.org/10.20431/2454-7670.0401003

Copyright:(C) 2018 Authors. This is an open-access article distributed under the terms of the Creative Commons Attribution License, which permits unrestricted use, distribution, and reproduction in any medium, provided the original author and source are credited. 